\title{
AZ ULTRAHANGOS DEFEKTOSZKÓPIA TANULMÁNYOZÁSA. ULTRAHANG-GENERÁTOR LAPKA ÉS ADATGYƯJTÓ INTERFÉSZ TERVEZÉSE
}

\author{
Égly István
}

\begin{abstract}
A dolgozat bemutatja az ultrahangos defektoszkópia felhasználását a fémekben található esetleges hibák felderítésében, majd kiemelve a jelek digitális feldolgozásának elớnyeit a hagyományos (analóg) eljárással szemben, rámutat egy mikroprocesszorral mûködố defektoszkóp elốnyeire.

A továbbiakban a dolgozat bemutatja egy ultrahang-generátor lapka és ezt egy IBM PC-vel (vagy ezzel kompatibilis számítógéppel) összekötó adatgyưjtó interfész tervezését. Az ultrahang-generátor lapkáról kapott analóg jelet az adatgyứjtố interfész digitális jellé alakítja át, majd egy 8 koktetes memóriában tárolja. A számítógép átveszi a jeleket, majd egy megfelelō program segítségével feldolgozza.

Az Igy létrehozott "digitális" defektoszkóp teljesítménye felülmúlja a hagyományos defektoszkópét,mivel új lehetõségeket biztosít, mint: az adatok tárolása, az adatok digitális feldolgozásának lehetõsége (különbözõ digitális szûrések), az eredmények távolságra való továbbításának lehetõsége, sıb.

A szerzõ hozzájárulása a két funkcionális lapka tervezésébõl, kísérletezésébõl és gyakorlati megvalósításából áll.
\end{abstract}

\section{A FÉMEK ULTRAHANGOS VIZSGÁLATA}

A ultrahangos vizsgálat egy viszonylag új módszer a fémtárgyak ellenőrzésében, melynek során az ellenốrzés alá vett fémtárgy belsejében található esetleges hibákat ki lehet mutatni.

Az ultrahangos vizsgálat lényege abból áll, hogy egy ultrahang-generátor segítségével ultrahangos rezgéseket továbbítanak az ellenôrizendó tárgyba. A tárgyban ezek a rezgések egy bizonyos formában megváltoznak, és a mérórendszer által kapott eredményt az arra szakosított személy (operátor) értelmezi.

A leginkább használt módszer a visszavert impulzus módszere, amely egyetlen elektroakusztikus átalakítót használ fel, amely egyszerre adó és vevó is. Az ultrahang impulzusok behatolnak az ellenôrzésnek alávetett tárgyba, és az impulzusok közötti idốintervallumban vételezik a visszatérố ultrahangokat. $\mathrm{Az}$ intermitensen küldött ultrahangok behatolnak a tárgyba és vagy a fém esetleges diszkontinuitásairól, vagy pedig a fémtárgy hátsó faláról visszaveródnek. A visszavert jeleket az elektroakusztikus traduktor elektromos jellé alakítja, majd erôsítés után az oszcilloszkópon megjelentethetốk a jelek.

Az elektroakusztikus traduktor egyik legfontosabb paramétere a központi frekvenciája (az úgynevezett rezonancia frekvenciája). Ha egy traduktor a rezonancia frekvenciájával megegyezó frekvenciájú impulzusokat kap, az általa generált ultrahang amplitúdója a lehetố legnagyobb lesz (ami azt jelenti, hogy az ultrahang energiája ebben az esetben a lehetó legnagyobb lesz).

Az ultrahangok jól terjednek szilárd és folyékony közegben, de a levegố kis akusztikus impedanciájával egy majdnem kifogástalan árnyékolást jelent az ipari ultrahangos vizsgálatnál 
használt frekvenciákra. A gyakorlatban a folytonosság biztosításáért egy úgynevezett összekötő közeget használnak, melynek az a szerepe, hogy kiiktassa a tárgy felületén levő levegôt (amely a tárgy és a traduktor közé kerülne). A gyakorlatban leggyakrabban használt közegek a víz, az olaj, a vazelin , stb.

Jelenleg a defektoszkópiai laboratóriumokban nagyobbrészt analóg elven múködő mérőmúszereket használnak, amelyek az elektroakusztikus traduktor által vett jeleket egy katódcsố segítségével vizualizálják.

A modern mérési módszerek feltételezik egyes, az adatok feldolgozásában használt digitális módszerek felhasználását (szúrés, analóg-digitális átalakítás, stb.) valamint "intelligens", processzor típusú elemek felhasználását, melyek az ellenôrzés folyamatát automatikussá teszik. Egy mikroprocesszor felhasználása a mérômúszert új tulajdonságokkal gazdagítja, mint például:

- a begyújtött adatok tárolása

- az eredmények távolságra való küldésének lehetôsége

- a begyújtött adatokat különböző digitális feldolgozások alá lehet vetni (például digitális szúrések).

\section{AZ ULTRAHANG-GENERÁTOR LAPKA TERVEZÉSE}

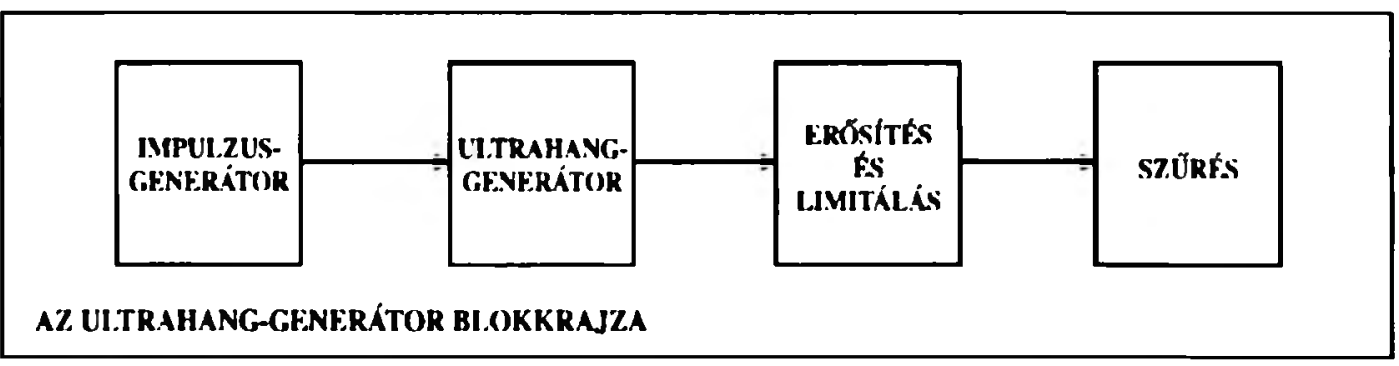

Az impulzusgenerátor egy változtatható hosszúságú impulzust generál, melyet úgy kell beállítani, hogy az impulzus frekvenciája megegyezzen az elektroakusztikus traduktor rezonanciafrekvenciájával. Ebben az esetben az elektroakusztikus traduktor maximális energiával töltődik fel, vagyis a gerjesztett ultrahangnak maximális lesz a teljesítménye, tehát az amplitúdója is (egy adott tápfeszuiltség esetén).

Az ultrahang-generátor bemenetére a traduktor rezonanciafrekvenciájára hangolt impulzus érkezik. Ezt az impulzust az elektroakusztikus traduktor egy csillapított rezgéssé alakítja, amely akusztikus hullámmá alakul. Az ultrahang behatol az ellenórzendó anyagba és a visszavert ultrahangot (amely sokkal kisebb amplitúdójú mint a beesố hullám) a traduktor visszaalakítja elektromos rezgéssé.

Az erôsítô és limitáló (határoló) egységnek az a szerepe, hogy a kis amplitúdójú (visszavert) elektromos rezgést annyira erôsítse fel, hogy a következó funkcionális egységek optimálisan dolgozhassák fel. A viszonylag nagy amplitúdójú beesô elektromos rezgést - melyet az elektroakusztikus traduktor generál az impulzus hatására - határolni kell, ellenkezó esetben ez a következő egység meghibásodásához vezetne.

Ahhoz hogy az analóg jelet vissza lehessen állítani a szaggatott jelből, Shannon tétele értelmében a szaggatási frekvencia legkevesebb kétszerese kell legyen az analóg jel maximális frekvenciájánál. A jelen esetben egy $2 \mathrm{MHz}$-es szinuszjelünk van, tehát Shannon tétele értelmében ahhoz, hogy a jelet vissza lehessen állítani a szaggatás után, a minimális szaggatási frekvencia $4 \mathrm{MHz}$ kell legyen. Mivel a kuantizálási (digitalizálási) hiba annál kisebb minél nagyobb a szaggatási frekvencia, a digitális-analóg átalakítás után kapott jel annál inkább 
hasonlít az eredeti jelre minél nagyobb a szaggatási frekvencia. Mivel ez az alkalmazás nagy pontosságot igényel a visszaállított jel szempontjából, a szaggatás $25 \mathrm{MHz}$-en történik. Gyakorlatilag ez azt jelenti, hogy a használt szúró csillapítása $12 \mathrm{MHz}$-en legkevesebb $54 \mathrm{~dB}$ kell legyen. Mivel a hasznos jel $2 \mathrm{MHz}-e s$, ezt a feltételt egy negyedfokú sáváteresztó szúrő́vel lehet optimálisan megoldani.

\section{AZ ADATGYƯJTŐ́ INTERFÉSZ}

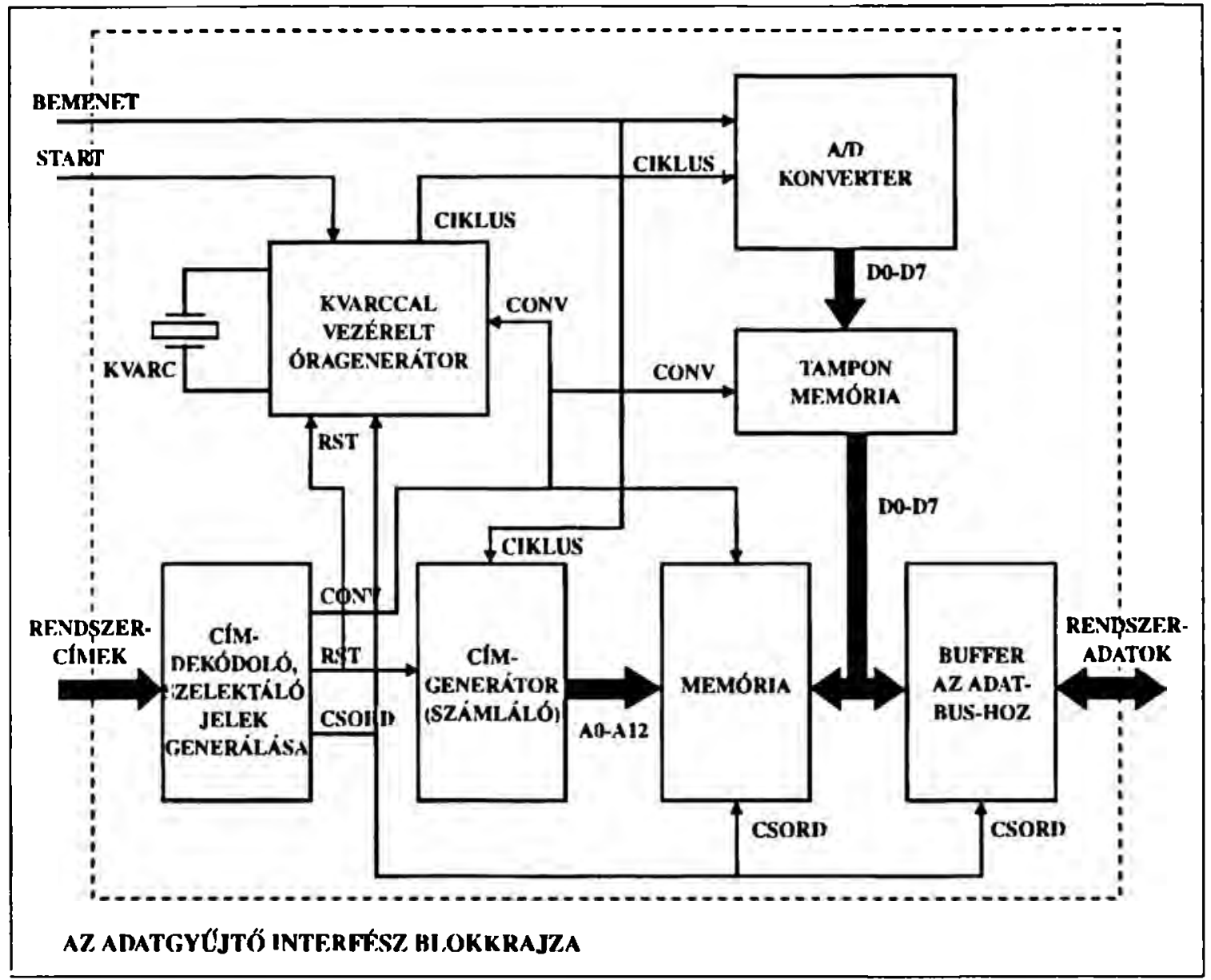

A szaggatási frekvencia meghatározza (fordított arányban) a szaggatott jel idôtartamát (hosszát). Vastag anyagok esetén kívánatos egy hosszabb szaggatási idótartam a szaggatási frekvencia hátrányára. Egy nagyobb frekvencia jobb felbontást biztosít, ezért ezt elónyös vékony anyagok esetén használni.

A szaggatott jel időtartamát a használt buffer (tampon memória) mérete határozza meg. A memória méretezésénél a szaggatási frekvencia értékét, az ultrahang terjedési sebességét különbözó anyagokban és a vizsgálandó tárgy maximális méretét kell figyelembe venni. A szükséges memória nagyságát a következó képlet adja meg:

$M=(21 / v) * f$

ahol: $\quad$ M - a szuikséges memória (byteokban) 
1 - az anyag vastagsága (a traduktor által vett jel kétszer teszi meg az anyag vastagságának megfelelố utat !) - legtöbb lm

$\mathrm{v}$ - az ultrahang terjedési sebessége az anyagban $(0,6-15 \mathrm{~mm} / \mathrm{us})$

$\mathrm{f}$ - a szaggatási frekvencia - $25 \mathrm{MHz}$

Mindezek alapján egy 8 koktetes memória felhasználása a legoptimálisabb.

$\mathrm{Az}$ egy szaggatásnak megfelelố digitális információ egy byte nagyságú lesz, amely 1/256-os amplitúdó felbontást tesz lehetôvé.

$\mathrm{Az}$ analóg-digitális átalakítás szempontjából optimális amplitúdójú jel egy nagy sebességư TDA8703-as analóg-digitális átalakító bemenetére kerül. Ez az átalakító 8 bites, tehát 256 szintes kuantizálást tesz lehetốvé, amely elegendố ehhez az alkalmazáshoz. A szaggatási frekvencia $25 \mathrm{MHz}$. Az átalakítás után kapott oktetek a 74LS245 -ös bufferen keresztül betöltődnek a 8 koktetes memóriába.

A 6264-es típusú memóriák hozzáférési ideje általában nagyobb, mint a szaggatás periódusa, amivel dolgozunk. Ezért a nagyfrekvenciájú digitális oszcilloszkópoknál használt speciális adatgyújtési és memorálási technikát kell alkalmazni, éspedig: egy periodikus jel szaggatása több ciklust elolvasva történik, mindegyik ciklus más és más idóegységgel van eltolva a triggeráló jelhez képest. Jelen esetben egy ciklus visszaállítása 4 egymás után következó ciklus beolvasásával történik. Ily módon a memória hozzáférése (80ns) belefér az átalakítás/írás ciklusba.

A memória címzése, úgy az írásnál mint az olvasásnál számlálók segítségével történik. Ezek a számlálók alkotják a címgenerátor blokkot. Az interfészt a számítógép úgy kezeli mint egy periféria lokációt. Az adatok gyors hozzáférhetőségének biztosítása érdekében egy periféria olvasó parancsot használunk.

A dekódoló egység dekódolja a rendszer címbusát, ezen az egységen keresztül valósul meg az adatgyưjtố interfész címzése a számítógép által.

A kiválasztó (szelektáló) jeleket generáló egység adja azokat a jeleket, melyek segítségével beállítódnak az adatgyújtés paraméterei és megindul az adatgyújités.

A kvarccal vezérelt órajelgenerátor állítja elố a szinkron áramkörök (analóg-digitális átalakító, számlálók) múködéséhez szükséges órajeleket.

Bibliográfia:

1. A.P. French - Vibrations and Waves (Thomas Nelson Ltd. London)

2. M. Scheffel, P. Stiuca - Dispozitive cu ultrasunete (Ed. Tehnicá, București, 1989)

3. G. Amza, D. Barb - Sisteme ultraacustice (Ed. Tehnică, București, 1988)

4. Dascălu - Dispozitive şi circuite electronice (EDP, Bucureşti, 1982)

Égly István, okl. villamosmérnök

Tel.: 064-167787 